\title{
Combating Nitrous Oxide Emission from Rice Field Using Soil Amendments
}

\author{
N. Kowshika ${ }^{1 *}$, N. Maragatham ${ }^{2}$, V. Geethalakshmi ${ }^{3}$, \\ M. Maheswari ${ }^{4}$ and S. Panneerselvam ${ }^{1}$
}

${ }^{1}$ Agro Climate Research Centre, ${ }^{2}$ Department of Farm Management, TNAU, Coimbatore- 641 003, Tamil Nadu, India

${ }^{3}$ Department of Agronomy, TNAU, Madurai, Tamil Nadu, India

${ }^{4}$ Department of SS \& AC, ADACRI, Trichy, Tamil Nadu, India

*Corresponding author

\section{A B S T R A C T}

\begin{tabular}{|l|}
\hline Ke y w or d s \\
Climate change, \\
Nitrous oxide \\
emission.
\end{tabular}

Rice cultivation is constantly blamed to be a contributor to climate change through the release of greenhouse gases to the atmosphere especially nitrous oxide, where nitrogenous fertilizers are used injudiciously. A step towards reducing the GHGs emission, an experiment was conducted with eight different soil amendments combinations viz., recommended dose of Fertilizers (RDF), fly ash, biochar, gypsum, Silica Solubilizing Bacteria (SSB), fly ash + SSB, biochar + SSB, gypsum + SSB were studied. Gas collection was done using chambers and samples were analyzed using Gas chromatography. Nitrous oxide emission was observed at active tillering, panicle initiation, 50 per cent flowering and maturity stages. During the crop growth, application of fly ash+ SSB had reduced emission rate followed by fly ash and gypsum + SSB. Higher nitrous oxide emission was found with the treatment of RDF followed by RDF + SSB, biochar, biochar + SSB and gypsum. From the study, it was concluded that application of fly ash + SSB did reduce the nitrous oxide emissions over the application of other soil amendments in rice field.

\section{Introduction}

Rice being an important food crop of Asia supplies 35 to 60 per cent of the calories of 2.7 billion Asians (Pingali et al., 1997). Cultivation of rice in India is mainly concentrated in delta areas, river valleys, and low lying coastal areas. Food and Agriculture Organization (FAO) set its 2015 production forecast as 158.2 million tonnes (FAO Rice Market Monitor, April 2016). Owing to the influence of the El Niño phenomenon, during 2016 season, FAO anticipates production in India improve to 158.4 million tonnes, up 2 per cent from 2015 expectations. Tamil Nadu ranks fifth position in rice production in India with an area of 21 lakhs ha, with a production of 92 lakh M.T. (Metric Tonnes) and a productivity of $4381 \mathrm{~kg} / \mathrm{ha}$ (Department of Agriculture, Tamil Nadu, 14th Executive Committee Meeting, National Food Security Mission, Department of Agriculture, Tamil Nadu, Nov, 2014). At present rice production is reported to be a contributor to climate change, through the release of greenhouse gases to the atmosphere such as nitrous oxide emissions. There is a need for action on climate change, but global warming has not 
been reduced to safe levels. Scientists around the world are tracking over a warming, exceeding $2^{\circ} \mathrm{C}$ by 2100 (IPCC, 2014), which would have far reaching consequences for food security, fresh water availability and the frequency and intensity of storms.

Nitrous oxide is one among the prominent greenhouse gases, being 298 times potential enough as $\mathrm{CO}_{2}$. Compared to other sectors, agriculture contributes disproportionately heavily to the emissions of methane and nitrous oxide, possibly in the 40-60\% range. Soils with nitrogen fertilizers release nitrous oxide, the most potent greenhouse gas. While agriculture releases significant amount $\mathrm{N}_{2} \mathrm{O}$ to the atmosphere, it can potentially be decreased by improving crop management (Smith et al., 2007). The problem starts where the major food driver is pointed as the major source of a greenhouse gas that needs attention towards emission reductions. A pace over reducing the nitrous oxide emissions can be done with application of soil amendments to the rice crop field.

\section{Materials and Methods}

\section{Field experiment}

A field experiment was conducted in Tamil Nadu Agricultural University, Coimbatore, Tamil Nadu during Rabi (2015-16) season. The short duration rice variety $\mathrm{CO}(\mathrm{R}) 51$ was used in RBD with three replications and eight treatments viz., recommended dose of fertilizers alone $\left(T_{1}\right)$, fly ash $\left(T_{2}\right)$, biochar $\left(\mathrm{T}_{3}\right)$, gypsum $\left(\mathrm{T}_{4}\right)$, silica solubilizing bacteria $\left(\mathrm{T}_{5}\right)$, flyash + silica solubilizing bacteria $\left(\mathrm{T}_{6}\right)$, biochar + silica solubilizing bacteria $\left(\mathrm{T}_{7}\right)$, gypsum + silica solubilizing bacteria $\left(\mathrm{T}_{8}\right)$. Recommended dose of fertilizers (RDF) of NPK at 150: $50: 50 \mathrm{~kg} / \mathrm{ha}$, flyash at $20 \mathrm{t} / \mathrm{ha}$, biochar at $10 \mathrm{t} / \mathrm{ha}$, gypsum at $500 \mathrm{~kg} / \mathrm{ha}$ and silica solubilizing bacteria (SSB) at 12.5 $\mathrm{kg} / \mathrm{ha}$ were the dosages applied. RDF was a default component in all the treatment combinations.

\section{Application of soil amendments}

Soil amendments and silica solubilizing bacteria were applied a day prior to transplanting into the plots with respective doses as given in treatment details.

\section{Collection of air samples}

Gas samples were collected from the field using static closed chamber technique (Jain et al., 1999). As described by Khosa et al., (2010) each chamber was placed on the soil surface with $4-5 \mathrm{~cm}$ inserted into the soil, 10 minutes prior to each sampling for equilibration to reduce the disturbance so as to minimize the disturbance to the sampling site.

Care was taken not to disturb the vegetation during the whole measurement program. After covering the plants with the chamber, four air samples were collected in Tedlar bags starting with zero time and subsequent sampling at an interval of 15 minutes using syringe and one way valve pump. As described by Jayadeva et al., (2009), the air samples were collected in the morning (09:00-10:00 hours) and in the evening (14:00-15:00 hours) and the average of morning and evening fluxes were used as the flux value for the day.

Collection of gas samples was done continuously for a week at critical stages of crop growth viz., active tillering, panicle initiation, flowering and maturity stages.

\section{Estimation of nitrous oxide}

The gas samples were analyzed in a Shimadzu GC-2014 gas chromatograph equipped with FID. 


\section{Results and Discussion}

Influence of soil amendments on nitrous oxide emission from rice field is depicted in Table 1.

The nitrous oxide emission was found increasing towards maturity stage, as aeration is obtained during the harvesting stage. During the crop growth, significantly higher nitrous oxide emission was noted in RDF (2.7 $\mathrm{kg} / \mathrm{ha})$ and RDF + SSB (2.5 kg/ha).

Lower nitrous oxide values were observed in applications of Fly ash + SSB $(2.1 \mathrm{~kg} / \mathrm{ha})$, Gypsum + SSB (2.2 kg/ha) and Fly ash (2.2 $\mathrm{kg} / \mathrm{ha}$ ) in all stages. Applications of Biochar $(2.4 \mathrm{~kg} / \mathrm{ha})$, Biochar + SSB $(2.3 \mathrm{~kg} / \mathrm{ha})$ and Gypsum (2.3 kg/ha) contributed to less nitrous oxide emissions than SSB.

Table.1 Nitrous oxide emissions in four stages under different treatments $(\mathrm{kg} / \mathrm{ha})$

\begin{tabular}{|l|c|c|c|c|c|}
\hline \multicolumn{1}{|c|}{ Treatment } & $\begin{array}{c}\text { Active } \\
\text { Tillering } \\
\text { (kg/ha) }\end{array}$ & $\begin{array}{c}\text { Panicle } \\
\text { Initiation } \\
\text { (kg/ha) }\end{array}$ & $\begin{array}{c}\mathbf{5 0 \%} \\
\text { Flowering } \\
\text { (kg/ha) }\end{array}$ & $\begin{array}{c}\text { Maturity } \\
\text { (kg/ha) }\end{array}$ & $\begin{array}{c}\text { Average } \\
\text { (kg/ha) }\end{array}$ \\
\hline RDF alone & 1.7 & 2.7 & 2.9 & 3.5 & 2.7 \\
\hline Flyash & 1.1 & 2.2 & 2.7 & 2.9 & 2.2 \\
\hline Biochar & 1.1 & 2.4 & 2.9 & 3.2 & 2.4 \\
\hline Gypsum & 1.2 & 2.3 & 2.8 & 3.0 & 2.3 \\
\hline SSB & 1.3 & 2.4 & 2.6 & 3.5 & 2.5 \\
\hline Flyash + SSB & 1.1 & 2.2 & 2.6 & 2.8 & 2.1 \\
\hline Biochar + SSB & 1.1 & 2.3 & 2.7 & 3.0 & 2.3 \\
\hline Gypsum + SSB & 1.1 & 2.3 & 2.7 & 2.8 & 2.2 \\
\hline
\end{tabular}

*RDF was applied in all the treatment combinations

Fig.1 Nitrous oxide emissions in four stages under different treatments $(\mathrm{kg} / \mathrm{ha})$

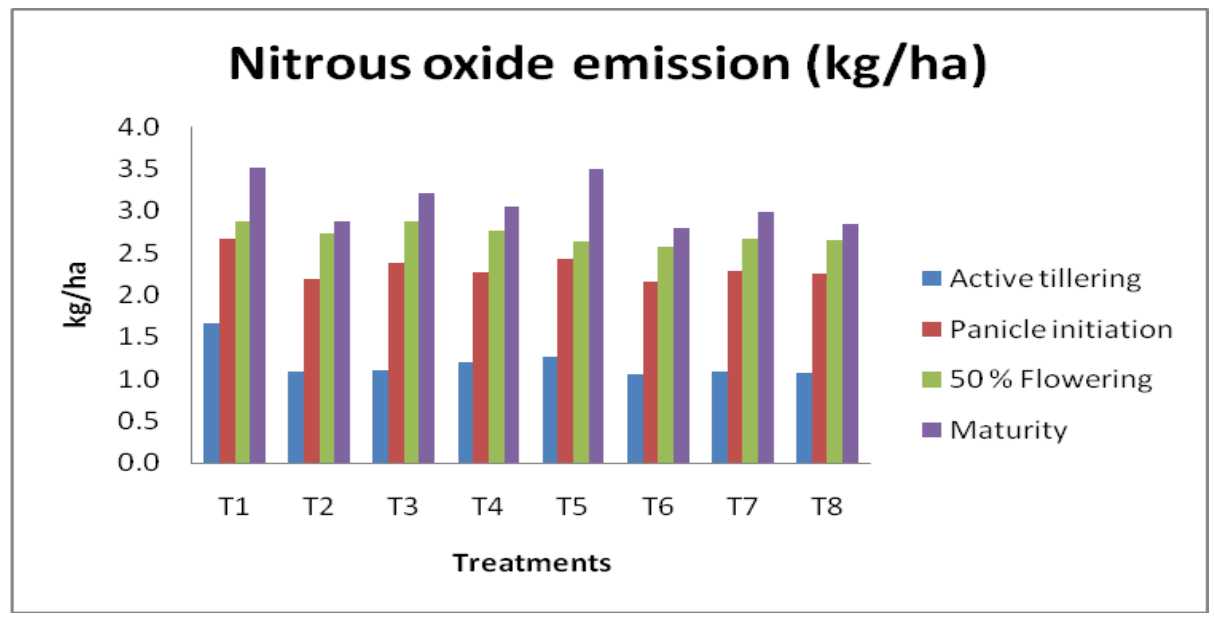

Nitrous oxide from rice field is mainly due to excess application of $\mathrm{N}$ fertilizer and faulty method and times of application of $\mathrm{N}$ (Nelson et al., 2012) in addition to drying of rice fields frequently during cropping season. This could be possible reason for increasing nitrous oxide emission towards maturity. There are investigations that focus on reducing the GHG 
emission by handling standard agronomic practices (Yadav et al., 2013) and soil amendment. The study has also met out the same purpose of reducing nitrous oxide emission. Use of fly-ash as soil ameliorant in place of lime could lead to reduction in $\mathrm{CO}_{2}$ equivalent emissions, thus contributing to minimize global warming (Ferreira et al., 2003).

Above results from the field study on nitrous emissions over application of soil amendments concluded that nitrous emissions could be reduced by the application of Fly ash + SSB, Gypsum + SSB and Flyash, biochar, biochar + SSB and Gypsum than the application of recommended dose of fertilizers. The soil amendments were found to help in reducing the nitrous oxide emissions from rice crop fields.

\section{References}

Department of Agriculture, Tamil Nadu. 2014. In: 14th Executive Committee Meeting, National Food Security Mission, Tamil Nadu, India.

FAO Rice Market Monitor. April 2016. 19:1. www.fao.org/economic/RMM.

Ferreira, C., Ribeiro A, Ottosen, L. 2003. Possible applications for municipal solid waste fly ash. J Hazard Mater. 96(2-3): 201-16.

IPCC, 2014: Climate Change 2014: Synthesis Report. Contribution of Working Groups I, II and III to the Fifth Assessment Report of the Intergovernmental Panel on Climate Change [Core Writing Team, R.K. Pachauri and L.A. Meyer (eds.)]. IPCC, Geneva, Switzerland, pp-151.

Jain, M. C., H. Pathak and Bhatia, A. 1999. Measurement of greenhouse gas emission from soil and developing emission inventories. In: Greenhouse Gas Emission from Soil. 65 - 78.

Jayadeva, H. M., T. K. Prabhakara Setty, R. C. Gowda, R. Devendra, G. B, Mallikarjun and Bandi, A. G. 2009. Methane emission as influenced by different crop establishment techniques and organic manures. Agric. Sci. Digest. 29(4): 241 245.

Khosa, M. K., B. S. Sidhu and Benbi, D. K. 2010. Effect of organic materials and rice cultivars on methane emission from rice field. J. Environ. Biol. 31: 281 - 285.

Nelson, M. C., M. Morrison, F. Schanbacher and $\mathrm{Yu}, \mathrm{Z}$. 2012. Shifts in microbial community structure of granular and liquid biomass in response to changes in feed and digester design in anaerobic digesters receiving food- processing waste. Bioresource Technology. 107: 135-143.

Pingali, P.L., M. Hossain and Gerpacio, R. V. 1997. Asian Rice Bowls - The Returning Crisis? CAB International, Wallingford.

Smith, P., D. Martino, Z. Cai, D. Gwary, H. Janzen, P. Kumar, B. McCarl, S. Ogle, F. O'Mara, C. Rice, B. Scholes, and Sirotenko, O. (2007) Agriculture. In: Metz, B., O. R Davidson, P. R. Bosch, R. Dave, Meyer, L.A. (eds) Climate Change 2007: Mitigation. Contribution of Working Group III to the Fourth Assessment Report of the Intergovernmental Panel on Climate Change. Cambridge University Press, Cambridge. 497-540.

Yadav, R. C., O. M. Prakash and Deswal, J. S. 2013. Biotechnology of Intra-Row Banding of Cynobacteria Leguminous Crops for Raising Yield Plateau of Cereals and Oilseeds. Int. J. Agron. and Plant Prod. U.K. (In Press)

\section{How to cite this article:}

Kowshika, N., N. Maragatham, V. Geethalakshmi, M. Maheswari and Panneerselvam, S. 2017. Combating Nitrous Oxide Emission from Rice Field Using Soil Amendments. Int.J.Curr.Microbiol.App.Sci. 6(11): 3024-3027. doi: https://doi.org/10.20546/ijcmas.2017.611.354 